

\title{
Exposure-response analysis of tigecycline in pharmacodynamic simulations using different size inocula of target bacteria
}

D. Sevillano, L. Aguilar, L. Alou, M.J. Giménez, N. González, M. Torrico, F. Cafini, C. Garcia-Rey, N. Garcia-Escribano, J Prieto

\section{To cite this version:}

D. Sevillano, L. Aguilar, L. Alou, M.J. Giménez, N. González, et al.. Exposure-response analysis of tigecycline in pharmacodynamic simulations using different size inocula of target bacteria. International Journal of Antimicrobial Agents, 2010, 36 (2), pp.137. 10.1016/j.ijantimicag.2010.03.021 . hal-00601190

\section{HAL Id: hal-00601190 https://hal.science/hal-00601190}

Submitted on 17 Jun 2011

HAL is a multi-disciplinary open access archive for the deposit and dissemination of scientific research documents, whether they are published or not. The documents may come from teaching and research institutions in France or abroad, or from public or private research centers.
L'archive ouverte pluridisciplinaire HAL, est destinée au dépôt et à la diffusion de documents scientifiques de niveau recherche, publiés ou non, émanant des établissements d'enseignement et de recherche français ou étrangers, des laboratoires publics ou privés. 


\section{Accepted Manuscript}

Title: Exposure-response analysis of tigecycline in pharmacodynamic simulations using different size inocula of target bacteria

Authors: D. Sevillano, L. Aguilar, L. Alou, M.J. Giménez, N. González, M. Torrico, F. Cafini, C. Garcia-Rey, N.

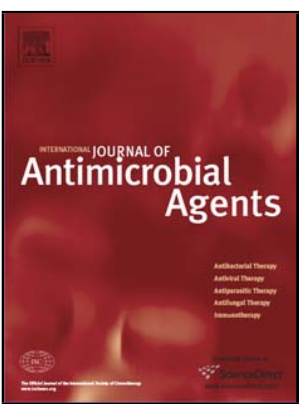
Garcia-Escribano, J Prieto

PII:

DOI:

Reference: S0924-8579(10)00154-8

To appear in: International Journal of Antimicrobial Agents

Received date: $\quad$ 27-11-2009

Revised date: $\quad 15-1-2010$

Accepted date: $\quad 10-3-2010$

Please cite this article as: Sevillano D, Aguilar L, Alou L, Giménez MJ, González N, Torrico M, Cafini F, Garcia-Rey C, Garcia-Escribano N, Prieto J, Exposureresponse analysis of tigecycline in pharmacodynamic simulations using different size inocula of target bacteria, International Journal of Antimicrobial Agents (2008), doi:10.1016/j.ijantimicag.2010.03.021

This is a PDF file of an unedited manuscript that has been accepted for publication. As a service to our customers we are providing this early version of the manuscript. The manuscript will undergo copyediting, typesetting, and review of the resulting proof before it is published in its final form. Please note that during the production process errors may be discovered which could affect the content, and all legal disclaimers that apply to the journal pertain. 


\section{Exposure-response analysis of tigecycline in pharmacodynamic simulations using different size inocula of target bacteria}

D. Sevillano ${ }^{\text {a }}$, L. Aguilar ${ }^{\text {a, }}$, L. Alou ${ }^{\text {a }}$, M.J. Giménez ${ }^{\text {a }}$, N. González ${ }^{a}$, M. Torrico $^{\text {a, }}$ F. Cafini ${ }^{\text {a }, ~ C . ~ G a r c i a-R e y ~}{ }^{\text {b }}$, N. Garcia-Escribano ${ }^{\text {b }}$, J Prieto ${ }^{\text {a }}$

${ }^{a}$ Microbiology Department, School of Medicine, Universidad Complutense, Avda. Complutense s/n, 28040 Madrid, Spain

${ }^{\mathrm{b}}$ Medical Department, Wyeth Farma S.A., Ctra. N-I, km. 23 Desvío Algete Km.1, San Sebastián de los Reyes, 28700 Madrid, Spain

ARTICLE INFO

Article history:

Received 27 November 2009

Accepted 10 March 2010

Keywords:

Staphylococcus aureus

Enterococcus faecium

Glycylcyclines

Pharmacodynamics

Inoculum effect

* Corresponding author. Tel.: +34 91394 1505; fax: +34 913941511. 
E-mail address: laguilar@med.ucm.es (L. Aguilar). 


\section{ABSTRACT}

This study explored tigecycline exposure-bacterial responses in pharmacodynamic simulations (in vitro kinetic model) using different inocula.

One meticillin-resistant vancomycin-heteroresistant Staphylococcus aureus, one Enterococcus faecium and one extended-spectrum $\beta$-lactamase-producing Escherichia coli with equal tigecycline minimum inhibitory concentrations/minimum bactericidal concentrations (MICs/MBCs) (0.12/0.25 $\mu \mathrm{g} / \mathrm{mL}$ ) were used. A computerised pharmacodynamic bicompartmental model simulated three tigecycline twice-daily dosing regimens over $48 \mathrm{~h}: 50 \mathrm{mg}$ (100 mg loading dose); 100 mg; and 150 mg. Areas under bacterial growth curves were calculated, and differences between the growth curve used as control and the killing curve of bacteria exposed to tigecycline (ABBC) were determined. With standard inocula [ca. $1 \times 10^{6}$ colony-forming units $(\mathrm{CFU}) / \mathrm{mL}$ ], linear increases in area under the concentration-time curve (AUC)/MIC (25.6 for 50 $\mathrm{mg}, 53.76$ for $100 \mathrm{mg}$ and 79.52 for $150 \mathrm{mg}$ ) produced linear increases in activity against Gram-positive organisms (mean ABBCs of 120.60, 143.20 and 195.80 $\log \mathrm{CFU} \times \mathrm{h} / \mathrm{mL}$ for $S$. aureus and of $95.75,172.55$ and $216.90 \log \mathrm{CFU}$ $\times \mathrm{h} / \mathrm{mL}$ for $E$. faecium, respectively), with the activity of the $150 \mathrm{mg}$ regimen being significantly higher $(P<0.01)$ than that of the other two regimens. ABBCs obtained with the $100 \mathrm{mg}$ regimen using standard inocula were similar to those obtained with the $150 \mathrm{mg}$ regimen when using high inocula (ca. $1 \times 10^{7}$ $\mathrm{CFU} / \mathrm{mL}$ ). Against $E$. coli, the highest dosing regimen was required to obtain significant antibacterial activity compared with control (mean ABBCs of 145.75 $\log \mathrm{CFU} \times \mathrm{h} / \mathrm{mL}$ with standard inocula and $63.33 \log \mathrm{CFU} \times \mathrm{h} / \mathrm{mL}$ with high inocula). An increase in tigecycline dosing appears to be an interesting 
therapeutic option to maximise antibacterial activity owing to its linear pharmacokinetics and pharmacodynamics, especially when severe infections with high bacterial load are suspected. 


\section{Introduction}

The emergence of metallo- $\beta$-lactamases (MBLs) and the increasing spread of extended-spectrum $\beta$-lactamases (ESBLs) $[1,2]$ among enterobacteria, together with vancomycin heteroresistance/tolerance linked to meticillin resistance in Staphylococcus aureus $[3,4]$ and vancomycin resistance in enterococci $[5,6]$, implies the need for new antibiotics against different bacterial targets in a field where the available antibiotic armamentarium is rapidly deteriorating due to these resistance traits.

Tigecycline is the first antibiotic of the glycylcycline class with a novel mechanism of action, preventing cross-resistance with antibiotics currently used against nosocomial Gram-positive organisms and ESBL-, AmpC-, carbapenemases or MBL-producing Gram-negative organisms [7], not exhibiting an inoculum effect against Enterobacteriaceae such as Klebsiella pneumoniae producing ESBLs and/or AmpC enzymes [8]. Tigecycline is currently approved by the US Food and Drug Administration (FDA) for the treatment of complicated skin and skin-structure infections (SSSIs), complicated intra-abdominal infections (IAIs) and community-acquired bacterial infections. Multidrug-resistant (MDR) Gram-positive pathogens such as meticillin-resistant S. aureus (MRSA) and vancomycin-resistant enterococci (VRE) are an increasing cause of nosocomial infections such as SSSIs (where high bacterial density is present) and bacteraemia [9]. Enterococci and Escherichia coli are the main facultative bacteria associated with secondary peritonitis (also with a high bacterial load) and secondary bacteraemia in severely ill patients [10]. 
The effectiveness of tigecycline in the treatment of severe infections by MDR bacteria (with borderline susceptibility) involving the bloodstream has not been clearly substantiated, and pharmacodynamic information may aid in further understanding the role of tigecycline [11]. This study aimed to explore tigecycline exposure-bacterial responses (using different initial inocula sizes) in dose-ranging in vitro pharmacodynamic simulations, since owing to its linear pharmacokinetics, concentration-dependent effect and bacteriostatic effects, maximising the effect by increasing the dose appears as an appealing therapeutic option [11].

\section{Material and methods}

\subsection{Strains}

Three clinical isolates chosen based on the same tigecycline minimum inhibitory concentrations/minimum bactericidal concentrations (MICs/MBCs) were used throughout the study: one MRSA showing heteroresistance to vancomycin determined as previously described [12]; one Enterococcus faecium; and one ESBL-producing E. coli (inhibitor-resistant TEM-34: IRT-6) characterised by $\beta$ lactamase polymerase chain reaction (PCR) amplification and direct sequencing as described previously [13]. Modal tigecycline MIC/MBC values (five determinations) were $0.12 / 0.25 \mu \mathrm{g} / \mathrm{mL}$ as determined by microdilution in Mueller-Hinton broth (Difco Laboratories, Detroit, MI) supplemented with calcium and magnesium (MHB) following Clinical and Laboratory Standards Institute recommendations $[14,15]$. In addition, since simulations were planned 
with two size inocula (see below), MICs were also determined using inocula of $10^{7}$ colony-forming units (CFU)/mL.

\subsection{In vitro kinetic model (Fig. 1)}

A two-compartment dynamic model exposing bacteria to changing study drug concentrations and avoiding dilution of the bacterial inoculum together with the drug was used [16]. The central compartment consisted of a spinner flask, the lumina of the capillaries within the dialyser (FX50 class; Fresenius Medical Care S.A., Barcelona, Spain) and the tubing in between. The peripheral compartment (infection site) was represented by the extracapillary space of the dialyser unit combined with the intradialyser circulating tubing. The high surface-area-tovolume ratio of the dialysis unit $\left(>200 \mathrm{~cm}^{2} / \mathrm{mL}\right)$ yields rapid equilibration of the concentration of the antimicrobial agent between the two compartments.

Before each experiment, the central compartment was filled with MHB. Decay of tigecycline concentrations in the central compartment was achieved by a continuous dilution-elimination process using computerised peristaltic pumps (Masterflex; Cole-Parmer Instrument Co. Ltd., Chicago, IL). Flow rates set in the peristaltic pumps were controlled using Win Lin software v.2 (Masterflex; ColeParmer Instrument Co. Ltd. ). In control drug-free simulations, the rate of peristaltic pumps was fixed to $0.12 \mathrm{~mL} / \mathrm{min}$. Additional pumps circulated the antimicrobial medium mixture at $50 \mathrm{~mL} / \mathrm{min}$ between the central and peripheral compartments and at $20 \mathrm{~mL} / \mathrm{min}$ within the extracapillary space through the external tubing. A computer-controlled syringe pump (402 Dilutor Dispenser; Gilson S.A, Villiers-le-Bel, France) allowed the simulation of 1-h infusion of 
tigecycline into the central compartment until a concentration similar to the target maximum concentration achieved in serum $\left(C_{\max }\right)$ was reached. Both compartments were maintained at $37^{\circ} \mathrm{C}$ over the entire simulation process.

\subsection{Kinetic simulations}

Serum total concentrations corresponding to three regimens of tigecycline administered by 1-h infusion were simulated over $48 \mathrm{~h}$ : (a) $50 \mathrm{mg}$ twice daily (with $100 \mathrm{mg}$ loading dose); (b) $100 \mathrm{mg}$ twice daily; and (c) $150 \mathrm{mg}$ twice daily. Mean population pharmacokinetic parameters of tigecycline described in a previous study using a two-compartmental model for multiple doses were used to determine the concentration-time profile of each regimen $(c=$ central; $p=$ peripheral): clearance $\mathrm{CL}_{c}=16.3 \mathrm{~L} / \mathrm{h}$; volume $V_{c}=57.7 \mathrm{~L} ; \mathrm{CL}_{p}=74.7 \mathrm{~L} / \mathrm{h}$; and $V_{p}=1030 \mathrm{~L}$ [17]. Mean values of pharmacokinetic parameters were introduced into a two-compartment model with an order 0 kinetic in the administration phase and a first-order kinetic in the elimination phase (see equation below) of the WinNonlin Professional program version 5.2 (Pharsight Corp., Mountain View, CA) and the concentration-time data over $48 \mathrm{~h}$ were obtained:

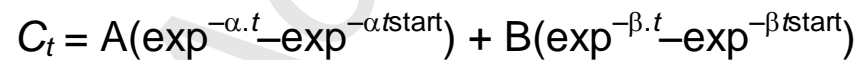

$$
\begin{aligned}
& \mathrm{A}=D / t i\left(V_{\mathrm{c}}\right) \cdot\left(\mathrm{K}_{21-\alpha}\right) /(\alpha-\beta) \cdot \alpha \\
& \mathrm{B}=-D / t i\left(V_{\mathrm{c}}\right) \cdot\left(\mathrm{K}_{21-\beta}\right) /(\alpha-\beta) \cdot \beta \\
& \mathrm{K}_{21}=\mathrm{CL}_{p} / V_{\mathrm{p}}
\end{aligned}
$$


where $C_{t}$ is the plasma concentration at time $t$ after the start of infusion, $t i$ is the length of the infusion, tstart $=t-t i, \alpha, \beta, A$ and $B$ are constants, $K_{21}$ is the transfer rate constant from the peripheral to the central compartment, and $D$ is the dose.

Target total concentrations were obtained by approximation of the biexponential decay of concentration-time curves of tigecycline to a sequence of 'pseudomonoexponential' profiles with different apparent elimination rate constants (Ke). Each segment in each time period was fitted using the expression:

$C_{t}=C_{0} \cdot \exp ^{-\mathrm{Ke} t}$

where $C_{0}$ is the residual concentration of previous periods.

Finally, the flow of the in vitro system was calculated using Ke according to the expression $F=\mathrm{Ke} . V_{\mathrm{d}}$, where $F$ is the flow and $V_{\mathrm{d}}$ is the volume of distribution (450 mL). Table 1 summarises the process-dependent pharmacokinetic parameters introduced in the computerised pharmacodynamic device.

\subsection{Pharmacokinetic analysis}

For measurement of simulated antimicrobial concentrations, aliquots $(0.5 \mathrm{~mL})$ were taken from the peripheral compartment at $0,1,2,4,6,8,10,12,13,24$, $25,26,28,30,32,34,36,37$ and $48 \mathrm{~h}$ in all simulations. All samples were stored at $-50{ }^{\circ} \mathrm{C}$ until use. Concentrations were determined by bioassay [18] 
using Bacillus cereus ATCC 11778 as the indicator organism (linear concentrations from $0.03 \mu \mathrm{g} / \mathrm{mL}$ to $2 \mu \mathrm{g} / \mathrm{mL}$; limit of quantitation $0.06 \mu \mathrm{g} / \mathrm{mL}$ ). Standards were prepared in the same broth employed in the pharmacokinetic simulation and were added to wells in the plates with the indicator organism. Plates were incubated for $18-24 \mathrm{~h}$ at $37^{\circ} \mathrm{C}$. Interday and intraday coefficients of variations were $5.28 \%$ and $2.22 \%$, respectively, for a tigecycline concentration of $0.75 \mu \mathrm{g} / \mathrm{mL}$.

Pharmacokinetic analysis was performed by a non-compartmental approach (model 200) using WinNonlin Professional program version 5.2. $C_{\max }$ and time to $C_{\max }\left(T_{\max }\right)$ were obtained directly from observed data. The area under the concentration-time curve from time 0 to $12 \mathrm{~h}$ (AUC) was calculated by the linear-log trapezoidal rule.

\subsection{Measurement of antibacterial effect}

Colonies from an overnight culture were allowed to grow in MHB to a density ranging from $1 \times 10^{8}$ to $2 \times 10^{8} \mathrm{CFU} / \mathrm{mL}$ as measured by an ultraviolet spectrophotometer (Hitachi U-1100; Hitachi, Tokyo, Japan). To obtain two different inocula sizes in simulations with the $100 \mathrm{mg}$ and $150 \mathrm{mg}$ tigecycline regimens, $6 \mathrm{~mL}$ of this bacterial suspension (for high inocula) or of a 1:10 dilution of the bacterial suspension (for standard inocula) were added into the peripheral compartment and incubated for $1 \mathrm{~h}$ to allow the microorganism to adapt to the medium. Samples $(0.5 \mathrm{~mL})$ were collected at $0,2,4,6,8,10,12$, $24,26,28,30,32,34,36$ and $48 \mathrm{~h}$ and were serially diluted in $0.9 \%$ sodium chloride. At least four dilutions of each sample $(20 \mu \mathrm{L})$ were spread onto 
Mueller-Hinton agar and overnight incubated for colony counting. The limit of detection was $50 \mathrm{CFU} / \mathrm{mL}$. Each experiment was performed in triplicate.

\subsection{Measurement of antibacterial activity and pharmacodynamic analysis}

Percentage reductions in initial inocula were calculated: $[(\mathrm{CFU} / \mathrm{mL}$ at time $0-$ $\mathrm{CFU} / \mathrm{mL}$ at each sampling time) $\times 100 \mathrm{j} / \mathrm{CFU} / \mathrm{mL}$ at time 0 . Antibacterial activity was also analysed as in previous studies $[16,19,20]$ by determining the area under the bacterial count-time curve (AUBC) $(\log \mathrm{CFU} \times \mathrm{h} / \mathrm{mL})$ as a measure of global killing along the experimental time $\left(\mathrm{AUBC}_{0-48}\right)$. AUBCs were calculated by the trapezoidal rule using the program GraphPad Prism 5.02 (GraphPad Software, San Diego, CA). Bacterial growth curves of the three strains in antibiotic-free simulations were used as controls. Differences between the growth curve used as control and the killing curve of bacteria exposed to tigecycline $(A B B C)(\log C F U \times h / m L)$ were determined.

The percentage of the dosing interval that simulated antibiotic concentrations exceeded the MIC (T>MIC) was calculated by a non-compartmental approach for pharmacodynamic data using model 220 of WinNonlin program version 5.2. $\mathrm{AUC}_{0-24} / \mathrm{MIC}$ (Table 2) were calculated using $\mathrm{AUC}_{0-24}$ calculated as follows: (a) for $100 \mathrm{mg}$ and $150 \mathrm{mg}$ tigecycline regimens, by the expression $2 \times \mathrm{AUC}_{0-12}$, where $\mathrm{AUC}_{0-12}$ is the $\mathrm{AUC}$ from 0 to $12 \mathrm{~h}$ (Day 1 ) or the $\mathrm{AUC}$ from $24 \mathrm{~h}$ to $36 \mathrm{~h}$ (Day 2); and (b) for the $50 \mathrm{mg}$ tigecycline regimen (with a $100 \mathrm{mg}$ loading dose), $\mathrm{AUC}_{0-24}$ for Day 1 was calculated by adding the $\mathrm{AUC}_{0-12}$ (after the $100 \mathrm{mg}$ loading dose) and the AUC from $24 \mathrm{~h}$ to $36 \mathrm{~h}$ (after the $50 \mathrm{mg}$ dose), and for Day 2 by the expression $2 \times \mathrm{AUC}_{0-12}$ (from $24 \mathrm{~h}$ to $36 \mathrm{~h}$ ). 


\subsection{Statistical analysis}

Per-strain comparisons of ABBCs obtained with each of the three antibiotic regimens were performed by analysis of variance (ANOVA). Owing to multiple comparisons, a $P$-value of $<0.01$ was considered significant.

\section{Results}

MICs determined with the high inocula $\left(10^{7} \mathrm{CFU} / \mathrm{mL}\right)$ increased four-fold from $0.12 \mu \mathrm{g} / \mathrm{mL}$ (determined with standard inocula) to $0.5 \mu \mathrm{g} / \mathrm{mL}$ for the two Grampositive organisms (S. aureus and E. faecium) and two-fold to $0.25 \mu \mathrm{g} / \mathrm{mL}$ for $E$. coli.

Fig. 2 shows concentration profiles (population-based serum profile, target and experimentally obtained), with near identity between the three curves for all tigecycline regimens tested. Table 2 shows pharmacokinetic and pharmacodynamic parameters of the three tigecycline regimens. With the 100 $\mathrm{mg}$ and $150 \mathrm{mg}$ regimens, the serum trough concentration $\left(C_{\mathrm{min}}\right)$ increased from Day 1 to Day 2 up to $>0.12 \mu \mathrm{g} / \mathrm{mL}$ (value of tigecycline MIC determined with standard inocula for the three strains tested), thus increasing T>MIC to $100 \%$. This did not occur with the $50 \mathrm{mg}$ regimen where, owing to the $100 \mathrm{mg}$ loading dose, similar $C_{\min }$ and AUC values were obtained on Days 1 and 2. In a similar way, $\mathrm{AUC}_{0-24} / \mathrm{MIC}$ values increased from Day 1 to Day 2 from 32.16 to 53.76 (67.16\% increase) for the $100 \mathrm{mg}$ regimen and from 50.56 to $79.52(57.28 \%$ 
increase) for the $150 \mathrm{mg}$ regimen, with a slight decrease for the $50 \mathrm{mg}$ regimen (from 27.76 to $25.60 ; 7.78 \%$ decrease).

Fig. 3 shows bacterial counts (log CFU/mL) over time for the three target bacteria obtained with the three tigecycline regimens using both inocula. Mean initial inocula $(\mathrm{CFU} / \mathrm{mL})$ were $1.2 \times 10^{6}, 3.8 \times 10^{6}$ and $3.7 \times 10^{6}$ (standard inocula) and $8.5 \times 10^{6}, 2.5 \times 10^{7}$ and $2.8 \times 10^{7}$ (high inocula) for $S$. aureus, $E$. faecium and E. coli, respectively. Initial inocula increased in control curves up to mean values $(\mathrm{CFU} / \mathrm{mL})$ of $\geq 1 \times 10^{8}$ at $12 \mathrm{~h}, \geq 3.2 \times 10^{8}$ at $24 \mathrm{~h}$ and $\geq 1 \times 10^{9}$ at 48 $\mathrm{h}$ for both Gram-positives, and up to $6.3 \times 10^{7}$ at $12 \mathrm{~h}, 1.3 \times 10^{8}$ at $24 \mathrm{~h}$ and $8.7 \times$ $10^{7}$ at $48 \mathrm{~h}$ for the E. coli strain.

Against $S$. aureus in simulations with standard inocula, reductions in initial inocula $>90 \%$ were obtained up to $12 \mathrm{~h}$ with the $50 \mathrm{mg}$ regimen, up to $28 \mathrm{~h}$ with the $100 \mathrm{mg}$ and up to $48 \mathrm{~h}$ with the $150 \mathrm{mg}$ tigecycline regimen. A similar picture was obtained against $E$. faecium, but with reductions $>99 \%$ from $12 \mathrm{~h}$ to $28 \mathrm{~h}$ with the $100 \mathrm{mg}$ regimen and from $6 \mathrm{~h}$ to $36 \mathrm{~h}$ with the $150 \mathrm{mg}$ regimen. In simulations carried out with high inocula, reductions $>90 \%$ were obtained up to $26 \mathrm{~h}$ for $\mathrm{S}$. aureus and up to $12 \mathrm{~h}$ for E. faecium with the $100 \mathrm{mg}$ tigecycline twice-daily regimen. When increasing the dose to $150 \mathrm{mg}$, the killing period was extended up to $36 \mathrm{~h}$ for both Gram-positives.

Against $E$. coli, the activity provided by the $50 \mathrm{mg}$ regimen was negligible, whilst with the $100 \mathrm{mg}$ regimen reduction rates up to $70 \%$ (for short time periods) were obtained regardless of the inoculum size. With the $150 \mathrm{mg}$ regimen, reductions 
$>99 \%$ were obtained from $24 \mathrm{~h}$ on in simulations using standard inocula and $>90 \%$ from $6 \mathrm{~h}$ to $34 \mathrm{~h}$ in simulations using high inocula.

Fig. 4 shows the effect of increasing doses of tigecycline regimens on the area under the bactericidal count-time curve $\left(\mathrm{AUBC}_{0-48}\right)$. As shown in Fig. 4, for Gram-positives in simulations using standard inocula, $\mathrm{AUBC}_{0-48}$ of controls (antibiotic-free) decreased ca. 35\% with the $50 \mathrm{mg}$ regimen, ca. 50\% with the $100 \mathrm{mg}$ regimen and ca. $65 \%$ with the $150 \mathrm{mg}$ regimen. When high inocula were used, $\mathrm{AUBC}_{0-48}$ of controls (antibiotic-free) decreased ca. $25 \%$ with the $100 \mathrm{mg}$ regimen and ca. 50\% with the $150 \mathrm{mg}$ regimen. In the case of E. coli, a reduction of control $\mathrm{AUBC}_{0-48}$ was only obtained with the $150 \mathrm{mg}$ regimen (ca. $50 \%$ with standard inocula and ca. $22 \%$ with high inocula simulations).

Finally, when measuring antibacterial activity as the difference between the growth curve in antibiotic-free simulations (controls) and the curve for each bacteria exposed to antibiotic (i.e. ABBC) (Table 3), significantly $(P<0.01)$ greater activity (i.e. significantly higher ABBC) was obtained with the $150 \mathrm{mg}$ regimen versus the $100 \mathrm{mg}$ regimen (and also versus the $50 \mathrm{mg}$ regimen) for the three study strains, regardless of the inocula size, whilst the ABBC of the $100 \mathrm{mg}$ regimen was only significantly higher than that of the $50 \mathrm{mg}$ regimen for E. faecium.

\section{Discussion}

Bacteraemia is usually of low-grade and transient, even in the absence of antimicrobial chemotherapy, provided that reseeding of blood does not occur 
[21]. Secondary bacteraemia from an infected tissue (where a high bacterial load is present) is more likely to have a fatal outcome than bacteraemia from a vascular catheter [22]. In this sense, the risk of development of severe sepsis is ten times higher for IAls than for urinary tract infections [23], and blood cultures are more commonly positive in patients with severe sepsis (and even more with septic shock) than in those with sepsis [24], with bacteraemia in this situation associated with mortality [25]. In addition, bloodstream infections with certain microorganisms such as MRSA or VRE (bacteria commonly isolated from deep wounds or debrided tissue in diabetic patients and also from nosocomial IAls in the case of VRE) have been often used as an imperfect surrogate outcome for severe sepsis/septic shock [21].

The broad antimicrobial spectrum and the large volume of distribution of tigecycline are usually employed as the rationale for its clinical use [26]. Tigecycline is currently approved for the treatment of complicated SSSIs, complicated IAls and community-acquired bacterial infections; other possible indications under discussion, facing the multidrug resistance field, involve bloodstream primary and secondary infections [21].

In this study, we explored the effect of different size inocula on the killing kinetic profile of the tigecycline standard dose (50 mg twice daily with a $100 \mathrm{mg}$ loading dose) and whether this effect can be overcome by increasing the dose in the dosing regimen, an opportunity provided by the linear pharmacokinetics of tigecycline and the reported safety profile and tolerability with doses ranging from $12.5 \mathrm{mg}$ to $300 \mathrm{mg}$ [27]. For this purpose, three target bacteria as 
representatives of isolates implicated in IAIs and SSSIs were used, namely $E$. coli, E. faecium and S. aureus. MICs of tigecycline determined with standard inocula $\left(0.125 \mu \mathrm{g} / \mathrm{mL}\right.$ for the three isolates) were similar to MIC $_{90}$ values (MIC for $90 \%$ of the organisms) for the three species in recently published surveillance studies [28,29]. According to FDA breakpoints $(\leq 0.5 \mu \mathrm{g} / \mathrm{mL}$ for $S$. aureus and $\leq 2 \mu \mathrm{g} / \mathrm{mL}$ for E. coll) [30] or British Society for Antimicrobial Chemotherapy breakpoints ( $\leq 0.5 \mu \mathrm{g} / \mathrm{mL}$ for $S$. aureus and $\leq 1 \mu \mathrm{g} / \mathrm{mL}$ for $E$. coli) [31], the $S$. aureus and E. coli isolates used in this study were susceptible to tigecycline (no breakpoints are available for E. faecium).

Previous in vitro and mouse models have suggested that tigecycline exhibits time-dependent action as well as a prolonged post-antibiotic effect [32]. In the present pharmacodynamic model, the increase in tigecycline dose increased the T>MIC (considering the MIC determined with standard inocula) from $30 \%$ for the $50 \mathrm{mg}$ regimen to $100 \%$ for the $100 \mathrm{mg}$ and $150 \mathrm{mg}$ regimens, but the 150 mg regimen exhibited significantly higher activity [when measured as AUBC (Fig. 4) or ABBC (Table 3)] than the $100 \mathrm{mg}$ regimen. If $T>\mathrm{MIC}$ was calculated with MICs determined with high inocula $(0.5 \mu \mathrm{g} / \mathrm{mL}$ for Gram-positives), values of $T>$ MIC were $12.5 \%$ and $22.5 \%$ for the $100 \mathrm{mg}$ and $150 \mathrm{mg}$ regimens, respectively, and despite these low values significant $A B B C$ s were found (higher with the $150 \mathrm{mg}$ regimen). Thus, in this in vitro model $T>\mathrm{MIC}$ appears not to be a good predictor of activity.

In a previous in vivo study, a relative reduction of bacterial $E$. coli density was found with subinhibitory concentrations $(T>\mathrm{MIC}=0 \%)$ [33]. In the present in 
vitro study, the situation for $E$. coli was different since despite $T>M I C$ values (30.4\% and $63.9 \%$ for the $100 \mathrm{mg}$ and $150 \mathrm{mg}$ regimens, respectively) higher than those obtained for the Gram-positives (MIC of $0.25 \mu \mathrm{g} / \mathrm{mL}$ for E. coli, high inocula), tigecycline activity against E. coli was significantly lower (lower ABBCs) and was negligible with the $100 \mathrm{mg}$ regimen in comparison with the activity depicted against Gram-positives (Table 3). Again, it appears that T>MIC is not the best predictor for all target bacteria.

This model simulates human pharmacokinetics of three increasing dose regimens based on the linear pharmacokinetics of tigecycline. This characteristic, together with its prolonged post-antibiotic effect, long half-life and high volume of distribution (implying that serum concentrations do not exactly predict concentrations at the infectious foci), are the basis to consider AUC/MIC as the most suitable pharmacodynamic parameter for prediction of microbiological and subsequent clinical efficacy with tigecycline $[27,33]$. In this sense, dose increases (from $50 \mathrm{mg}$ to $150 \mathrm{mg}$ ) produced linear increases in AUC/MIC (MIC using standard inocula) at Day 2 (from 25.6 to 79.52) and subsequent linear increases in antibacterial activity (ABBCs) against Grampositives (mean values increasing from 120.60 to $195.80 \log \mathrm{CFU} \times \mathrm{h} / \mathrm{mL}$ for $S$. aureus and from 97.75 to $216.90 \log \mathrm{CFU} \times \mathrm{h} / \mathrm{mL}$ for E. faecium) (Table 3 ). When using MIC determined with high inocula $(0.5 \mu \mathrm{g} / \mathrm{mL}$ for Gram-positives) for AUC/MIC calculation, the increase in AUC/MIC from 13.44 (100 mg regimen) to 19.88 (150 $\mathrm{mg}$ regimen) produced an increase in ABBCs from 67.92-91.05 log CFU $\times \mathrm{h} / \mathrm{mL}$ to ca. $155 \log \mathrm{CFU} \times \mathrm{h} / \mathrm{mL}$. These data are in accordance with previous clinical studies suggesting that AUC/MIC values of 
17.9 predict efficacy against $S$. aureus producing complicated skin and softtissue infections [34] and support the proposed value of $0.25-0.5 \mu \mathrm{g} / \mathrm{mL}$ as the clinical breakpoint for susceptibility for $S$. aureus, pharmacodynamically based on the AUC/MIC identified by Classification and regression tree (CART) analysis and subsequently used in Monte Carlo simulations [35].

As a general finding, against Gram-positives the activity (ABBCs) provided by the $150 \mathrm{mg}$ regimen in simulations using high inocula was similar to the activity observed with the $100 \mathrm{mg}$ regimen when using standard inocula.

The situation was completely different for $E$. coli since, in the current study, the proposed value of $0.25-0.5 \mu \mathrm{g} / \mathrm{mL}$ as the clinical breakpoint for susceptibility [35] did not correlate with antibacterial activity (measured as AUBC or ABBC), which was only obtained when the tigecycline dose was increased to $150 \mathrm{mg}$. It has been suggested that AUC/MIC values of 6.96 are needed for bacteriological efficacy against $E$. coli in IAls [36], but in the present study higher values (obtained with the $100 \mathrm{mg}$ regimen) did not correlate with pharmacodynamically significant ABBCs. Regardless of the inocula, significant ABBCs were only obtained when the tigecycline dose was increased to $150 \mathrm{mg}$. From the results obtained in this study testing only one E. coli strain, it appears that higher AUC/MIC values are needed for bacteriological efficacy against this target bacterium (in contrast to Gram-positives). However, it should be taken into account that in vitro pharmacodynamic simulations do not include factors such as immunity or surgical drainage that have a clear influence in the in vivo situation. In this sense, it has been postulated that while data generated in 
neutropenic animals define the pharmacodynamic parameter, the magnitude of the parameter relative to human pharmacodynamic targets is best defined in immunocompetent models [33].

One limitation of this study is that it does not take into account protein binding (80\%) [17] for tigecycline. The use of human albumin is technically and economically not feasible in two-compartmental systems that are more suitable than one-compartmental systems to simulate serum profiles (such as that of tigecycline) with a pronounced clearance in the first period, since twocompartmental systems prevent massive elimination of microorganisms during initial periods (with high clearance). However, protein binding was addressed in a recently published study by our group which showed that the presence of human albumin at physiological concentrations in broth did not significantly alter the antibacterial activity of tigecycline concentrations in killing curves against the same isolates [37].

Other limitations of this study are the limited $48 \mathrm{~h}$ duration of the experiments, the fact that only three selected strains were tested (one per species) and the simulation of serum concentrations.

Study strains were selected (same tigecycline MIC and MBC values) in order to explore, on a species basis, the effect of the linear increase in tigecycline pharmacokinetic/pharmacodynamics. The MBC/MIC ratio of 2 for all species in this study correlates with $\mathrm{MBC}_{90}$ and $\mathrm{MIC}_{90}$ values reported in a previous 
surveillance study [38] in the case of MRSA but not for E. coli since the $\mathrm{MBC}_{90} / \mathrm{MIC}_{90}$ ratio in the abovementioned study was 8.

Simulation of tigecycline serum concentrations is a limitation of the study because serum concentrations of tigecycline do not exactly predict concentrations at the infectious foci owing to its high volume of distribution. $\mathrm{AUC}_{0-24}$ values in bile, gallbladder, colon and lungs are 573-, 23-, 2.6- and 2times higher than the $\mathrm{AUC}_{0-24}$ in serum [39]. Therefore, pharmacodynamics based on serum concentrations may predict the bacterial load decrease over time in bacteraemia where inocula are expected to be lower than in tissue infections (or infectious foci) where a higher bacterial density is present but also higher tigecycline concentrations are achieved. None the less, the results of this study showed that the increase in the tigecycline dose in regimens to maximise effectiveness in severe infections appears an interesting therapeutic option owing to its linear pharmacokinetics and pharmacodynamics against Grampositives in the present study, especially when infections with high bacterial load are suspected.

\section{Acknowledgment}

The authors thank A. Perez for continuous scientific support.

\section{Funding}

This study was supported in part by an unrestricted grant from Wyeth Farma

S.A. (San Sebastian de los Reyes, Madrid, Spain). 


\section{Competing interests}

NG-E is an employee of Wyeth Farma S.A. (Madrid, Spain), not owning stock or options in the company. CG-R was an employee of Wyeth Farma S.A. at the time of the study, not owning stock or options in the company. All other authors declare no competing interests.

\section{Ethical approval}

Not required. 


\section{References}

[1] $\mathrm{Ku} \mathrm{YH}$, Chuang YC, Yu WL. In vitro activity of tigecycline against clinical isolates of extended-spectrum $\beta$-lactamase-producing Klebsiella pneumoniae, Serratia marcescens and Enterobacter cloacae. J Microbiol Immunol Infect 2008;41:332-6.

[2] Woodford N, Zhang J, Warner M, Kaufmann ME, Matos J, Macdonald A, et al. Arrival of Klebsiella pneumoniae producing KPC carbapenemase in the United Kingdom. J Antimicrob Chemother 2008;62:1261-4.

[3] Jones RN. Microbiological features of vancomycin in the 21st century: minimum inhibitory concentration creep, bactericidal/static activity, and applied breakpoints to predict clinical outcomes or detect resistant strains. Clin Infect Dis 2006;42(Suppl 1):S13-4.

[4] Tenover FC, Moellering Jr RC. The rationale for revising the Clinical and Laboratory Standards Institute vancomycin minimal inhibitory concentration interpretive criteria for Staphylococcus aureus. Clin Infect Dis $2007 ; 44: 1208-15$.

[5] Lentino JR, Narita M, Yu VL. New antimicrobial agents as therapy for resistant Gram-positive cocci. Eur J Clin Microbiol Infect Dis 2008;27:3-15.

[6] Saribas S, Bagdatli Y. Vancomycin tolerance in enterococci. Chemotherapy $2004 ; 50: 250-4$.

[7] Sorlózano A, Gutiérrez J, Salmerón A, Luna JD, Martínez-Checa F, Román $\mathrm{J}$, et al. Activity of tigecycline against clinical isolates of Staphylococcus aureus and extended-spectrum $\beta$-lactamase-producing Escherichia coli in Granada, Spain. Int J Antimicrob Agents 2006;28:532-6. 
[8] Conejo M, Hernàndez J, Pascual A. Comparative activity of tigecycline, cefepime and imipenem against clinical isolates of Klebsiella pneumoniae producing extended spectrum $\beta$-lactamases, plasmid-mediated AmpC-type $\beta$-lactamases or both, associated or not with porin deficiency. Clin Microbiol Infect 2007;13(Suppl. 1)/Int J Antimicrob Agents 2007;29(Suppl 2):S199. In: Abstracts of the 17th European Congress of Clinical Microbiology and Infectious Diseases (ECCMID)/25th International Congress of Chemotherapy (ICC) Congress; Munich, Germany; 31 March-3 April 2007. Abstract no. 1733_290.

[9] Florescu I, Beuran M, Dimov R, Razbadauskas A, Bochan M, Fichev G, et al. Efficacy and safety of tigecycline compared with vancomycin or linezolid for treatment of serious infections with methicillin-resistant Staphylococcus aureus or vancomycin-resistant enterococci: a Phase 3, multicentre, doubleblind, randomized study. J Antimicrob Chemother 2008;62(Suppl 1):i17-28.

[10] Moellering RC. Enterococcus species, Streptococcus bovis, and Leuconostoc species. In: Mandell GL, Bennett JE, Dolin R, editors. Mandell, Douglas, and Bennett principles and practice of infectious diseases. 6th ed. Philadelphia, PA: Elsevier Churchill Livingston; 2005. p. 2411-21.

[11] Falagas ME, Karageorgopoulos DE, Dimopoulos G. Clinical significance of the pharmacokinetic and pharmacodynamic characteristics of tigecycline. Curr Drug Metab 2009;10:13-21.

[12] Walsh TR, Bolmstrom A, Qwarnstrom A, Ho P, Wootton M, Howe RA, et al. Evaluation of current methods for detection of staphylococci with reduced susceptibility to glycopeptides. J Clin Microbiol 2001;39:2439-44. 
[13] Rodríguez-Baño J, Navarro MD, Romero L, Martínez-Martínez L, Muniain MA, Perea EJ, et al. Epidemiology and clinical features of infections caused by extended-spectrum $\beta$-lactamase-producing Escherichia coli in nonhospitalized patients. J Clin Microbiol 2004;42:1089-94.

[14] Clinical and Laboratory Standards Institute. Methods for dilution antimicrobial susceptibility tests for bacteria that growth aerobically; approved standard. 7th ed. Document M7-A7. Wayne, PA: CLSI; 2006.

[15] National Committee for Clinical Laboratory Standards. Methods for determining bactericidal activity of antimicrobial agents; approved guideline. Document M26-A. Wayne, PA: NCCLS; 1999.

[16] González N, Aguilar L, Alou L, Giménez MJ, Sevillano D, Torrico M, et al. Influence of different resistance traits on the competitive growth of Haemophilus influenzae in antibiotic-free medium and selection of resistant populations by different $\beta$-lactams: an in vitro pharmacodynamic approach. $\mathrm{J}$ Antimicrob Chemother 2009;63:1215-22.

[17] Van Wart SA, Cirincione BB, Ludwig EA, Meagher AK, Korth-Bradley JM, Owen JS. Population pharmacokinetics of tigecycline in healthy volunteers. J Clin Pharmacol 2007;47:727-37.

[18] Andrews JM. Microbiological assays. In: Reeves DS, Wise R, Andrews JM, White LO, editors. Clinical antimicrobial assays. 1st ed. Oxford, UK: Oxford University Press; 1999. p. 35-44.

[19] Firsov AA, Saverino D, Ruble M, Gilbert D, Manzano B, Medeiros AA, et al. Predictors of effect of ampicillin-sulbactam against TEM- $1 \beta$-lactamaseproducing Escherichia coli in an in vitro dynamic model: enzyme activity versus MIC. Antimicrob Agents Chemother 1996;40:734-8. 
[20] White R, Friedrich L, Burgess D, Warkentin D, Bosso J. Comparative in vitro pharmacodynamics of imipenem and meropenem against Pseudomonas aeruginosa. Antimicrob Agents Chemother 1996;40:904-8.

[21] Munford RS. Sepsis, severe sepsis, and septic shock. In: Mandell GL, Bennett JE, Dolin R, editors. Mandell, Douglas, and Bennett principles and practice of infectious diseases. 6th ed. Philadelphia, PA: Elsevier Churchill Livingston; 2005. p. 906-26.

[22] Renaud B, Brun-Buisson C; ICU-Bacteremia Study Group. Outcomes of primary and catheter-related bacteremia. A cohort and case-control study in critically ill patients. Am J Respir Crit Care Med 2001;163:1584-90.

[23] Brun-Buisson C, Doyon F, Carlet J. Bacteremia and severe sepsis in adults: a multicenter prospective survey in ICUs and wards of 24 hospitals. French Bacteremia-Sepsis Study Group. Am J Respir Crit Care Med $1996 ; 154: 617-24$.

[24] Rangel-Frausto MS, Pittet D, Costigan M, Hwang T, Davis CS, Wenzel RP. The natural history of the systemic inflammatory response syndrome (SIRS). A prospective study. JAMA 1995;273:117-23.

[25] Brun-Buisson C, Doyon F, Carlet J, Dellamonica P, Gouin F, Lepoutre A, et al. Incidence, risk factors, and outcome of severe sepsis and septic shock in adults. A multicenter prospective study in intensive care units. French ICU Group for Severe Sepsis. JAMA 1995;274:968-74.

[26] Doan TL, Fung HB, Mehta D, Riska PF. Tigecycline: a glycylcycline antimicrobial agent. Clin Ther 2006;28:1079-106. 
[27] Muralidharan G, Micalizzi M, Speth J, Raible D, Troy S.

Pharmacokinetics of tigecycline after single and multiple doses in healthy subjects. Antimicrob Agents Chemother 2005;49:220-9.

[28] Kresken M, Leitner E, Seifert H, Peters G, von Eiff C. Susceptibility of clinical isolates of frequently encountered bacterial species to tigecycline one year after the introduction of this new class of antibiotics: results of the second multicentre surveillance trial in Germany (G-TEST II, 2007). Eur J Clin Microbiol Infect Dis 2009;28:1007-11.

[29] Nørskov-Lauritsen N, Marchandin H, Dowzicky MJ. Antimicrobial susceptibility of tigecycline and comparators against bacterial isolates collected as part of the TEST study in Europe (2004-2007). Int J Antimicrob Agents 2009;34:121-30.

[30] US Food and Drug Administration. TYGACIL ${ }^{\circledR}$ prescribing information. http://www.accessdata.fda.gov/drugsatfda_docs/label/2009/021821s013s01 7s018lbl.pdf [accessed 9 April 2010].

[31] British Society for Antimicrobial Chemotherapy. BSAC methods for antimicrobial susceptibility testing. Version 9 January 2010. http://www.bsac.org.uk/db/_documents/Version_9_January_2010_final.pdf [accessed 15 April 2010].

[32] Meagher AK, Ambrose PG, Grasela TH, Ellis-Grosse EJ. Pharmacokinetic/pharmacodynamic profile for tigecycline-a new glycylcycline antimicrobial agent. Diagn Microbiol Infect Dis 2005;52:165-71.

[33] Nicasio AM, Crandon JL, Nicolau DP. In vivo pharmacodynamic profile of tigecycline against phenotypically diverse Escherichia coli and Klebsiella pneumoniae. Antimicrob Agents Chemother 2009;53:2756-61. 
[34] Meagher AK, Passarell JA, Cirincione BB, Van Wart SA, Liolios K, Babinchak T, et al. Exposure-response analyses of tigecycline efficacy in patients with complicated skin and skin-structure infections. Antimicrob Agents Chemother 2007;51:1939-45.

[35] MacGowan AP. Tigecycline pharmacokinetic/pharmacodynamic update. J Antimicrob Chemother 2008;62(Suppl 1):i11-6.

[36] Passarell JA, Meagher AK, Liolios K, Cirincione BB, Van Wart SA, Babinchak T, et al. Exposure-response analyses of tigecycline efficacy in patients with complicated intra-abdominal infections. Antimicrob Agents Chemother 2008;52:204-10.

[37] Alou L, Giménez MJ, Cafini F, Aguilar L, Sevillano D, González N, et al. In vitro effect of the presence of human albumin physiological concentrations on tigecycline antibacterial activity against Gram-positive and Gram-negative bacteria. J Antimicrob Chemother 2009;64:1230-3.

[38] Zhang YY, Zhou L, Zhu DM, Wu PC, Hu FP, Wu WH, et al. In vitro activities of tigecycline against clinical isolates from Shanghai, China. Diagn Microbiol Infect Dis 2004;50:267-81.

[39] Rodvold KA, Gotfried MH, Cwik M, Korth-Bradley JM, Dukart G, EllisGrosse EJ. Serum, tissue and body fluid concentrations of tigecycline after a single $100 \mathrm{mg}$ dose. J Antimicrob Chemother 2006;58:1221-9. 
Fig. 1. Diagram of the in vitro computerised device.

Fig. 2. Concentration profiles of the tigecycline regimens tested: serum population profile (- - -); target profile (-); and experimentally measured concentrations $(\bullet)$ in the peripheral compartment (infection site).

Fig. 3. Bacterial counts $\left[\log _{10}\right.$ colony-forming units $\left.(\mathrm{CFU} / \mathrm{mL})\right]$ over time for the three target bacteria obtained in simulations carried out with standard and high inocula with the three tigecycline twice-daily regimens: antibiotic-free controls (-



Fig. 4. Area under the bacterial count-time curve from $0-48 \mathrm{~h}\left(\mathrm{AUBC}_{0-48}\right)[\log$ colony-forming units $(\mathrm{CFU}) \times \mathrm{h} / \mathrm{mL}$ ] using standard inocula and high inocula for the different tigecycline twice-daily regimens: control (antibiotic-free); $50 \mathrm{mg}$ (with a $100 \mathrm{mg}$ loading dose); $100 \mathrm{mg}$; and $150 \mathrm{mg}$ tigecycline. 


\section{Table 1}

Process-dependent pharmacokinetic parameters introduced in the computerised pharmacodynamic device

\begin{tabular}{llll}
\hline Process & Time period $(\mathrm{h})$ & $\mathrm{Ke}\left(\mathrm{h}^{-1}\right)$ & $\mathrm{CL}(\mathrm{L} / \mathrm{h})$ \\
\hline Dose 1 & & & \\
Order 0 infusion & $0-1$ & 0.00 & 0.00 \\
Monoexponential decay & $1-3$ & 1.13 & 0.51 \\
Monoexponential decay & $3-4$ & 0.32 & 0.15 \\
Monoexponential decay & $4-12$ & 0.02 & 0.01 \\
Dose 2 & & & \\
Order 0 infusion & $12-13$ & 0.00 & 0.00 \\
Monoexponential decay & $13-15$ & 0.93 & 0.42 \\
Monoexponential decay & $15-16$ & 0.20 & 0.09 \\
Monoexponential decay & $16-24$ & 0.02 & 0.01 \\
Dose 3 & & & \\
Order 0 infusion & $24-25$ & 0.00 & 0.00 \\
Monoexponential decay & $25-27$ & 0.82 & 0.37 \\
Monoexponential decay & $27-28$ & 0.15 & 0.07 \\
Monoexponential decay & $28-36$ & 0.02 & 0.01 \\
Dose 4 & & & \\
Order 0 infusion & $36-37$ & 0.00 & 0.00 \\
Monoexponential decay & $37-39$ & 0.75 & 0.34 \\
Monoexponential decay & $39-40$ & 0.12 & 0.05 \\
Monoexponential decay & $40-41$ & 0.02 & 0.01 \\
\hline Ke, apparent elimination rate & & & \\
\hline
\end{tabular}

$\mathrm{Ke}$, apparent elimination rate constant; $\mathrm{CL}$, clearance. 


\section{Table 2}

Pharmacokinetic/pharmacodynamic parameters of the three tigecycline twice-daily regimens

\begin{tabular}{|c|c|c|c|c|c|c|}
\hline \multirow{2}{*}{ Pharmacokinetic parameters } & \multicolumn{3}{|l|}{ Day 1} & \multicolumn{2}{|l|}{ Day 2} & \\
\hline & & & & & & \\
\hline Regimen (mg twice daily) & $50^{a}$ & 100 & 150 & $50^{a}$ & 100 & 150 \\
\hline$C_{\max }(\mu \mathrm{g} / \mathrm{mL})$ & $0.88 \pm 0.12$ & $0.88 \pm 0.11$ & $1.38 \pm 0.10$ & $0.45 \pm 0.03$ & $1.00 \pm 0.12$ & $1.53 \pm 0.16$ \\
\hline$C_{\min }(\mu \mathrm{g} / \mathrm{mL})$ & $0.06 \pm 0.00$ & $0.07 \pm 0.02$ & $0.12 \pm 0.02$ & $0.06 \pm 0.01$ & $0.15 \pm 0.04$ & $0.21 \pm 0.04$ \\
\hline $\mathrm{AUC}_{0-12}(\mu \mathrm{g} \mathrm{h} / \mathrm{mL})($ mean \pm S.D. $)$ & $1.87 \pm 0.25$ & $2.01 \pm 0.36$ & $3.16 \pm 0.47$ & $1.60 \pm 0.10$ & $3.36 \pm 0.56$ & $4.97 \pm 0.42$ \\
\hline $\mathrm{AUC}_{0-24}(\mu \mathrm{g} \mathrm{h} / \mathrm{mL})$ (mean) & 3.47 & 4.02 & 6.32 & 3.20 & 6.72 & 9.94 \\
\hline \multicolumn{7}{|l|}{ Pharmacodynamic parameters } \\
\hline \multicolumn{7}{|c|}{ Staphylococcus aureus, Enterococcus faecium and Escherichia coli: MICs $/ \mathrm{MBCs}=0.125 / 0.25 \mu \mathrm{g} / \mathrm{mL}$} \\
\hline$C_{\max } / \mathrm{MIC}$ & 7.04 & 7.04 & 11.04 & 3.60 & 8.00 & 12.24 \\
\hline $\mathrm{AUC}_{0-24} / \mathrm{MIC}$ & 27.76 & 32.16 & 50.56 & 25.60 & 53.76 & 79.52 \\
\hline T>MIC (\% dosing interval) & 26.9 & 29.5 & 86.5 & 30.0 & 100 & 100 \\
\hline
\end{tabular}

$C_{\max }$, maximum serum concentration; $C_{\min }$, trough serum concentration; $\mathrm{AUC}_{0-x}$, area under the concentration-time curve from 0 to $x \mathrm{~h}$ (see Section 2.6); MIC, minimum inhibitory concentration; MBC, minimum bactericidal concentration; T>MIC, percentage of the dosing interval that simulated antibiotic concentrations exceeded the MIC; S.D., standard deviation.

a $100 \mathrm{mg}$ as loading dose followed by $50 \mathrm{mg}$ twice daily. 


\section{Table 3}

Antibacterial activity of the different tigecycline regimens in terms of ABBC (log $\mathrm{CFU} \times \mathrm{h} / \mathrm{mL})^{\mathrm{a}}$

\begin{tabular}{|c|c|c|c|c|}
\hline \multirow{2}{*}{ Organism } & \multirow[t]{2}{*}{ Inoculum } & \multicolumn{3}{|c|}{ Tigecycline regimen (mg twice daily) } \\
\hline & & $50^{\mathrm{b}}$ & 100 & 150 \\
\hline \multirow{3}{*}{$\begin{array}{l}\text { Staphylococcus } \\
\text { aureus }\end{array}$} & Standard & $120.60 \pm$ & $143.20 \pm$ & $195.80 \pm$ \\
\hline & & 10.89 & 15.70 & 20.65 \\
\hline & High & $\mathrm{N} / \mathrm{D}$ & $91.05 \pm 7.00$ & $\begin{array}{c}156.35 \pm \\
20.01\end{array}$ \\
\hline \multirow[t]{2}{*}{$\begin{array}{l}\text { Enterococcus } \\
\text { faecium }\end{array}$} & Standard & $95.75 \pm 4.88$ & $\begin{array}{c}172.55 \pm \\
1.93\end{array}$ & $\begin{array}{c}216.90 \pm \\
70.01\end{array}$ \\
\hline & High & $\mathrm{N} / \mathrm{D}$ & $\begin{array}{c}67.92 \pm \\
18.69\end{array}$ & $\begin{array}{l}155.90 \pm \\
0.71\end{array}$ \\
\hline \multirow[t]{2}{*}{ Escherichia coli } & Standard & $29.80 \pm 4.81$ & $11.15 \pm 4.13$ & $\begin{array}{l}145.75 \pm \\
0.35\end{array}$ \\
\hline & High & $N / D$ & $-3.42 \pm 5.04$ & $63.33 \pm 8.39$ \\
\hline
\end{tabular}

CFU, colony-forming units; N/D, not determined.

${ }^{a} A B B C=$ difference between the area under the growth control curve and the area under the bactericidal curve (AUBC) for each regimen (area under the growth control curve: $315.80 \pm 11.46 \log \mathrm{CFU} \times \mathrm{h} / \mathrm{mL}$ for $S$. aureus, $328.15 \pm$ 13.22 $\log \mathrm{CFU} \times \mathrm{h} / \mathrm{mL}$ for $E$. faecium and $294.55 \pm 4.45 \log \mathrm{CFU} \times \mathrm{h} / \mathrm{mL}$ for $E$. coli).

b $100 \mathrm{mg}$ as loading dose followed by $50 \mathrm{mg}$ twice daily. 


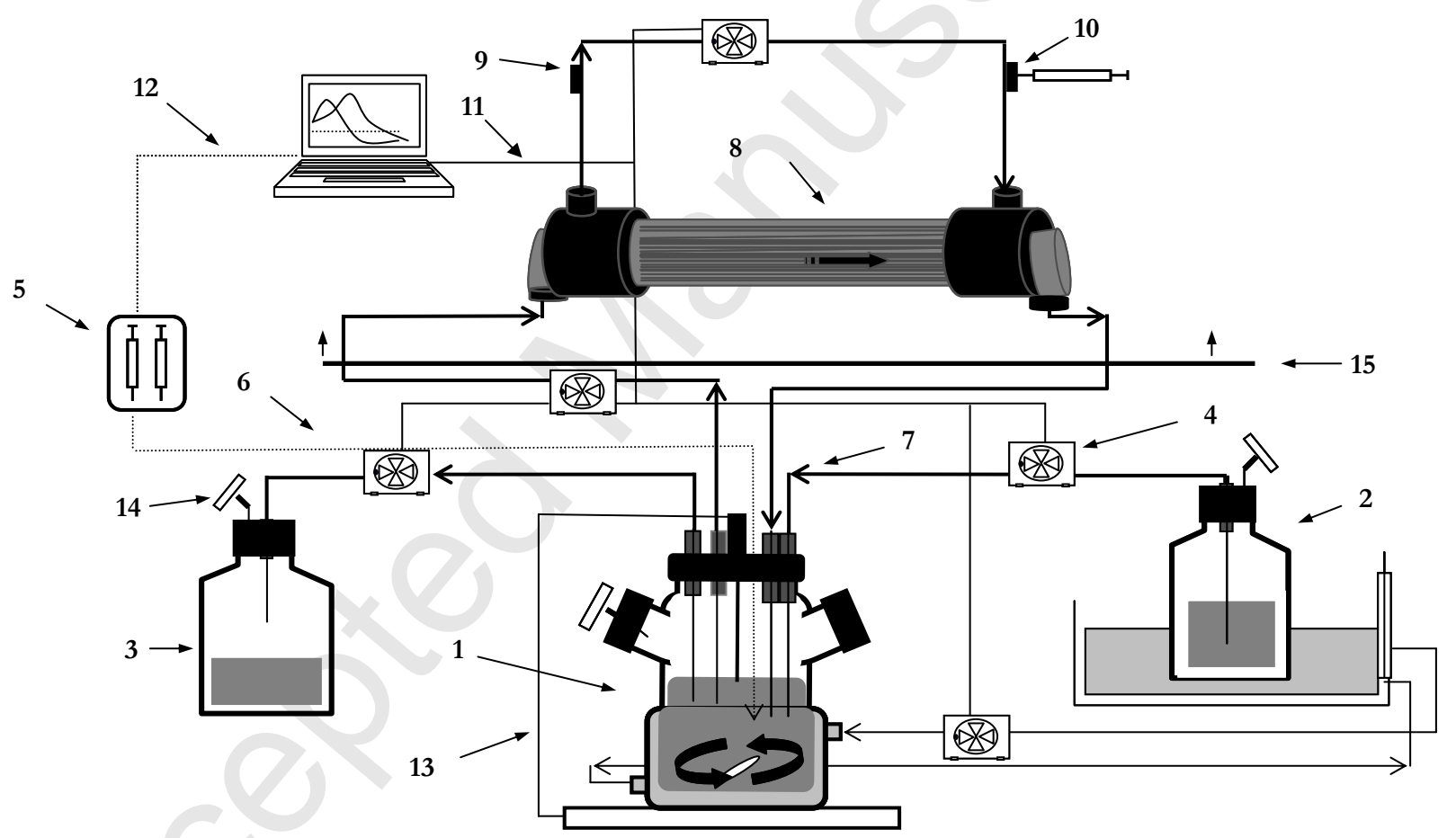

1. Central compartment (spinner flask, tubing and lumen of capillary), 2. Fresh broth reservoir, 3. Elimination, 4. Peristaltic pumps, 5. Syringe pump, 6. PTFE tubing, 7. Silicone tubing, 8. Infection compartment (Extracapillary space), 9. Inoculation port, 10. Sample port, 11. RS-232 connection, 12. GSIOC connection, 13. Temperature probe, 14. Air filter y 15. Incubator. 

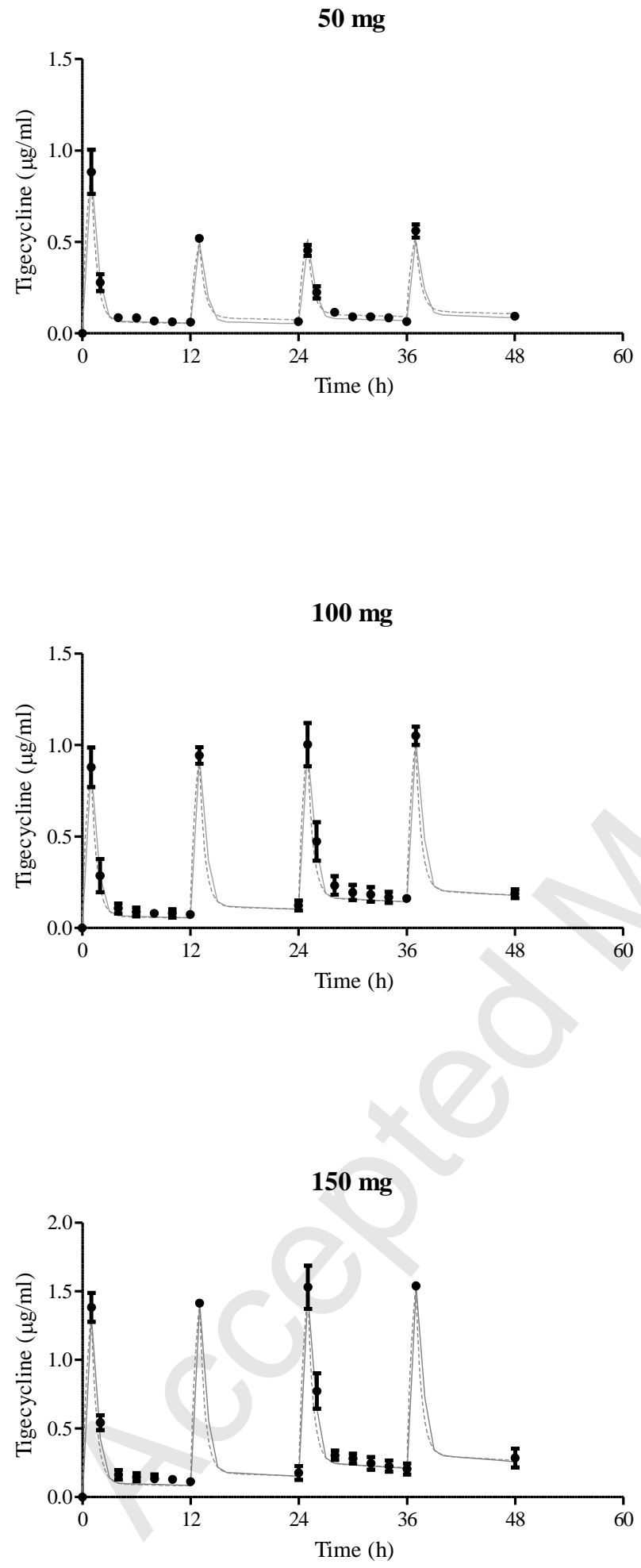


\section{S. aureus}
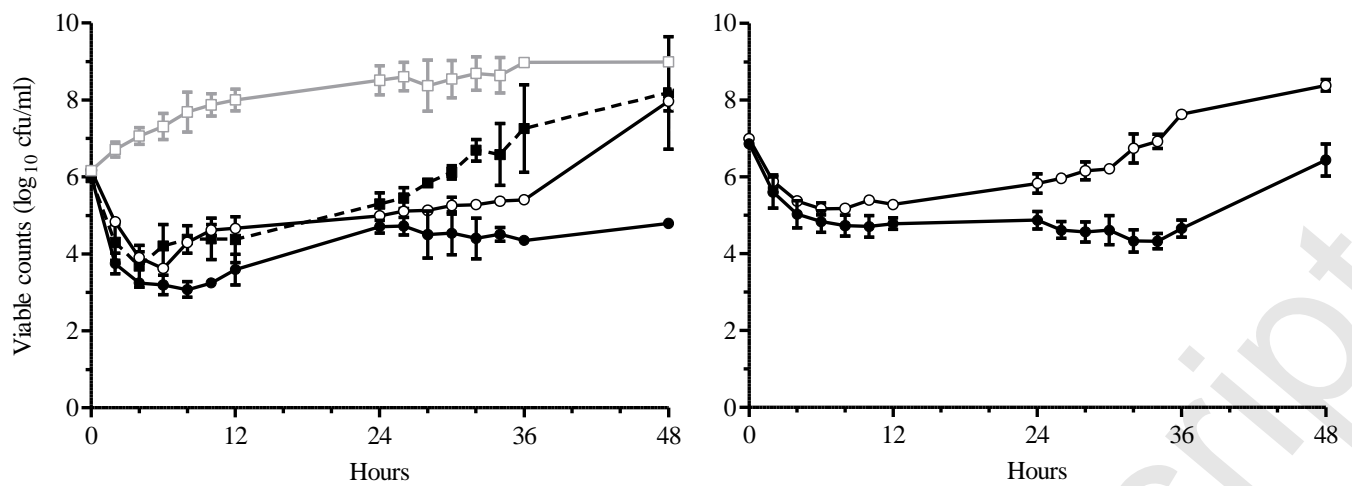

\section{E. faecium}
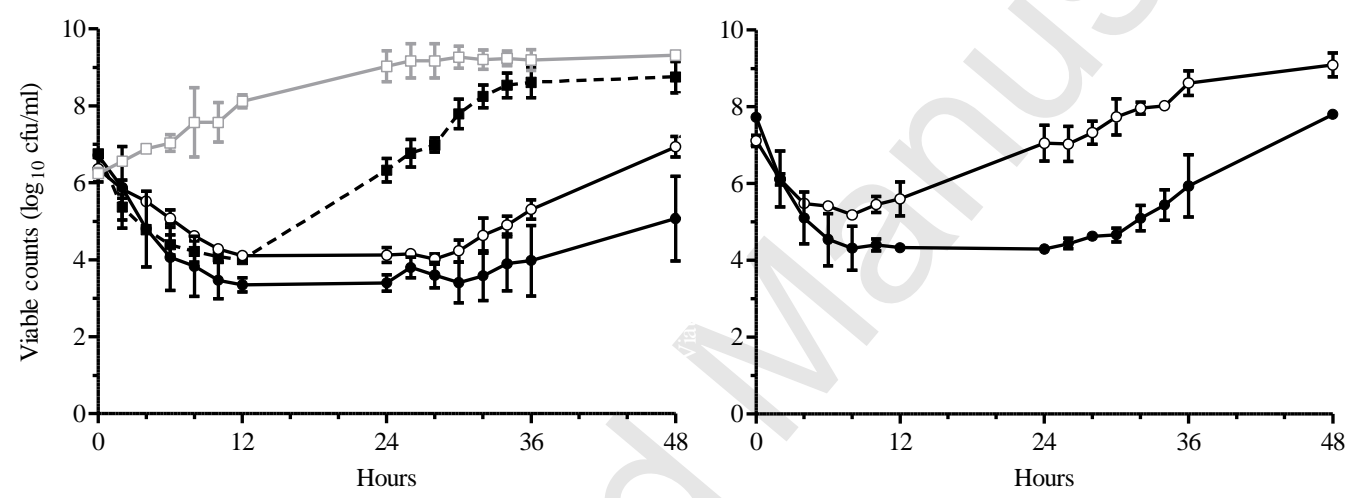

E. coli
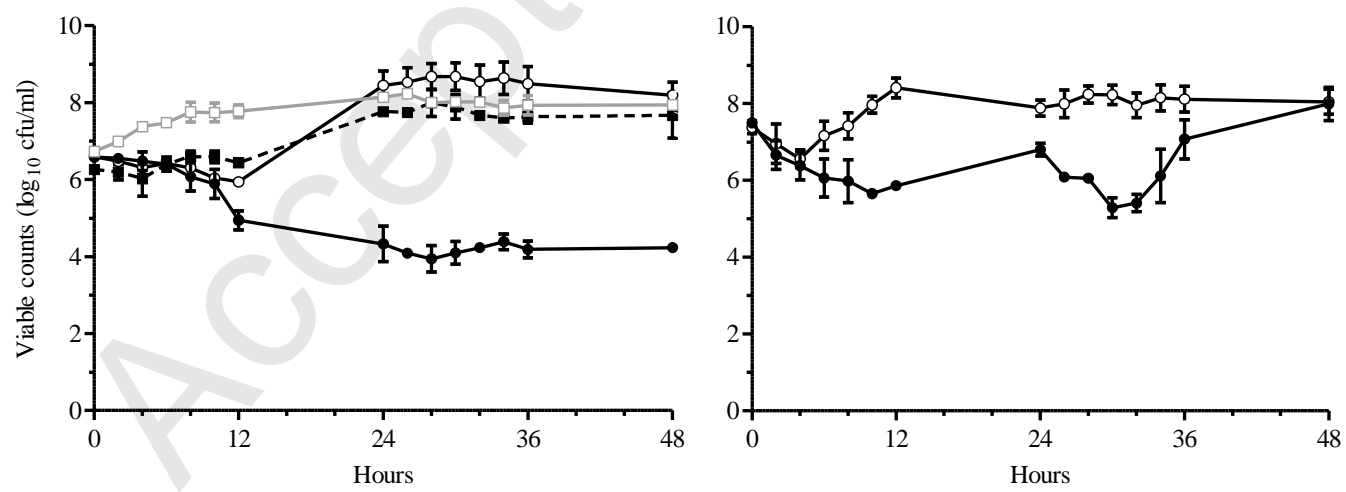


\section{S. aureus}

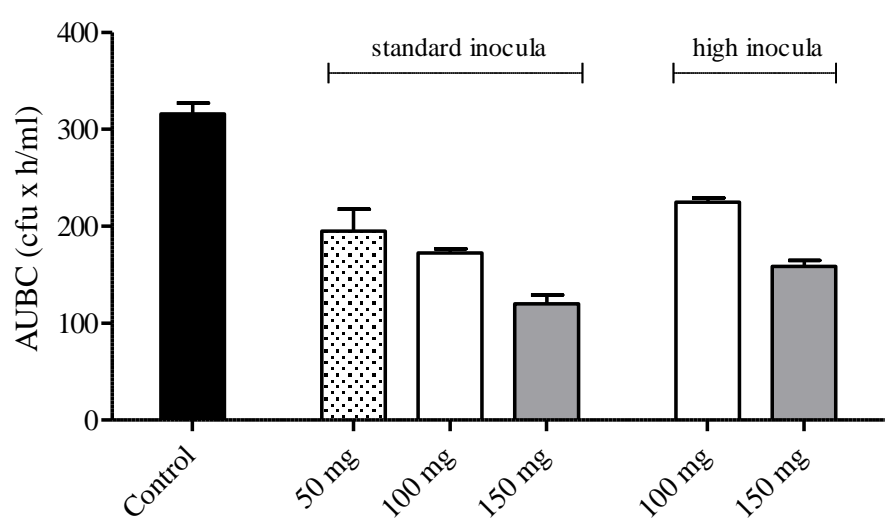

\section{E. faecium}

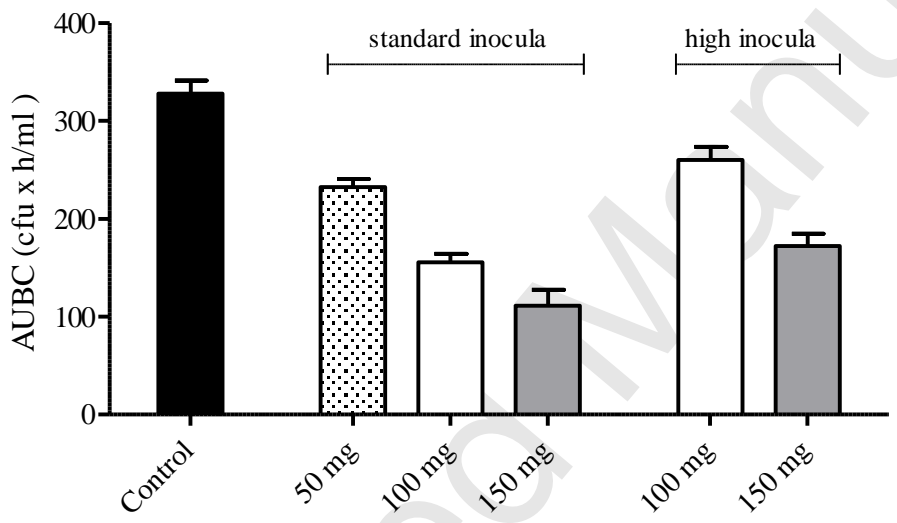

E. coli

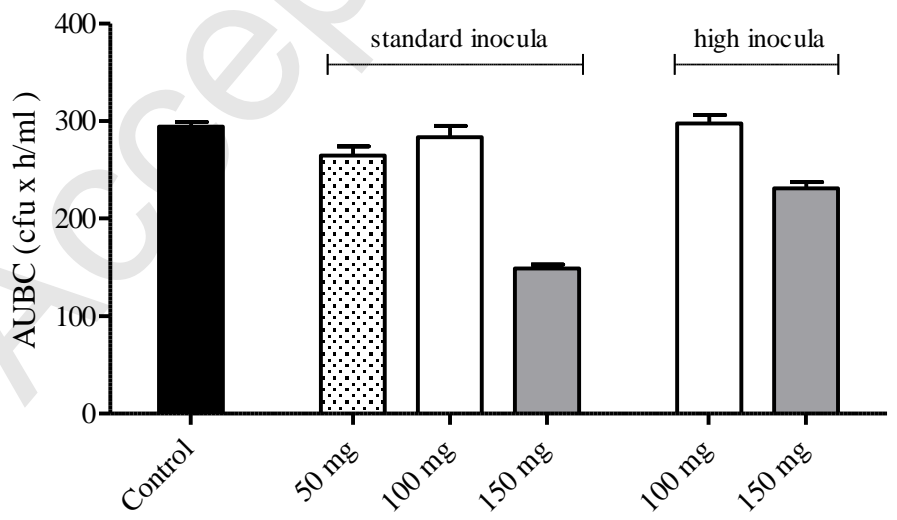

